\title{
Analysis of (Multi Village) Rural Regional Piped Water Supply Scheme - A case study
}

\author{
Vaishali Bharambe ${ }^{1}$, Dr.A.S.Wayal ${ }^{2}$ \\ ${ }^{I}$ M.Tech scholar, Civil and Environmental Engineering Dept., VJTI, Mumbai-400019. \\ ${ }^{2}$ Associate Professor, Civil and Environmental Engineering Dept., VJTI, Mumbai-400019.
}

\begin{abstract}
Rural water supply systems that cover more than one village are becoming increasingly common in India. Multi-village water supply schemes have the potential to capture economies of scale and to facilitate higher levels of service, and they appear to offer a feasible and long-term solution to the acute water scarcity faced by many regions in India. The challenges of providing sustainable access to rural water services in developing countries often go far beyond that of the technology itself. Aghai rural regional water supply scheme includes 24 habitations of Bhiwandi and SahapurTakula of Thane district was study area. Documents were collected and several site visits were carried out for assessment of scheme. Findings of the scheme are Basic layout of network, rough operational schedule, ESR filling operations and timing, rough service level at each habitation. Main issue of scheme is insufficient manpower for operation and maintenance of scheme. Check capacities of current assets to meet current and future demand. This scheme has further scope to be used in future with certain replacement of assets and by carrying proper operation and maintenance of scheme.
\end{abstract}

Keywords: Rural regional scheme, assessment, piped water supply scheme

\section{Introduction}

In India rural water supply mainly carried out either single village scheme or multi village scheme. While most of villages are served by single village schemes. Rural water supply systems that cover more than one village are becoming increasingly common in India. The desire to provide full water supply coverage to rural areas, Multi-village water supply schemes have the potential to capture economies of scale and to facilitate higher levels of service, and they appear to offer a feasible and long-term solution to the acute water scarcity faced by many regions in India. According to Indian constitution water is subject of state. The state of Maharashtra is leading in the field of improvements and decentralization of rural water supply and sanitation.

The challenges of providing sustainable access to rural water services in developing countries often go far beyond that of the technology itself. Indeed, many water systems (wells, gravity-fed systems, etc.) tend to fail or operate suboptimally due to a myriad of social, environmental and political factors that confound water service sustainability (Walters and Chinowsky, 2016). Functional sustainability of a rural water service, or its ability to provide the same quantity and quality of water over time, among other factors, depends on asustainable financing mechanism (KulinkinaandKosinski, 2016). Research has shown that the vast majority of cost recovery mechanisms in low-income settings do not collect sufficient funds for operation and maintenance (O\&M) of water systems, much less retain reserve funds to cover the costs of extending water services as communities grow. Low revenue streams are common due to a combination of low water tariffs and willingness to pay, low waterconsumption (Brikke and Rojas, 2001), and a lack of reliable accounting and auditing processes. Over the past decade, water security has gained significant attention, thereby improving the understanding of the concept by both policy makers and academicians. Many factors influence water security, including hydrology, population growth, increased migration, contamination of water resources, increased per capita water consumption, over-abstraction of groundwater, and climate change.(MrittikaBasu and Satoshi Hoshino, Shizuka Hashimoto, 2015 )

Government of India (GOI) and States have expended more than \$2billion per annum, for rural water and sanitation in the last few decades. However, it has not turned in to necessary level of services. Many studies report that ground reality is different from what is officially reported. There is a stark difference between ground reality and what is reported by government. To know the causes of failures of schemes, functioning of different implementing departments across the states, their technical capabilities in use of modern technological interventions like, computer.

Aghai rural regional water supply scheme is located in Thane district of Maharashtra state. This scheme was funded by world bank. Maharashtra government rural development section, technically sanction the scheme in 1991. It includes 16 villages and 8 habitation of Bhiwandi and SahapurTakula of Thane district. Scheme became functional in 1996. Aghai rural regional scheme is about $100 \mathrm{Km}$ from Thane. Out of 24 habitation 21 habitations are from Sahapurtahsil and 3 habitations are from BhiwandiTahsil. 


\section{A) Description of scheme}

\section{Methodology and Data Collection}

The source of Aghai rural regional water supply scheme is the raw water pipeline running from Vaitrana Dam towards Mumbai. The $200 \mathrm{~mm}$ CI pipe is used, to draw water from pipeline to the treatment plant. Connection had taken from vaitarna and tansa BMC raw water main line near Taharpur village weir no. A.M. 269 to A.M. 270. Water treatment plant consists of mixing chamber, floculator and tube settler. From WTP water is pumped to two MBR.one of them is located near WTP which serve 16 habitations having capacity $1,60,000$ liters. Another MBR is located at Vedhvhal village nearly $2.5 \mathrm{Km}$ from WTP having Capacity is 45,000 liters. A.C class 15 pipe of different diameter are used for transmission main. Length of gravity main is $28,982 \mathrm{~m}$. Consist of many valves such as air valve sluice valve. ESR is constructed at every habitation. RCC tank or plastic tanks are used at different location according to required capacity of habitation. Villages served by MBR near WTP are discussing in this paper.

Documents related to scheme such as detail project report, electricity bills, water bills, operation and maintenance documents were collected from rural water supply department of Sahapur panchayat samitii. Population data of last few decades were collected from census library at Sanpada, Navi Mumbai. Carried out few site visits to understand the scheme and for service level assessment of scheme. Findings of the scheme are Basic layout of network, rough operational schedule, ESR filling operations and timing, rough service level at each habitation.

\section{A) Current status of scheme}

\section{Problem Statement}

Out of 16 habitations scheme is only functional in 12 villages only. Water is continuously taken from BMC raw water main line to WTP in between 7 AM to 5.30 PM. MBR is filled twice in a day but during same time outlet of MBR is also opened. Habitation supply schedule is as follow.

Table 1.Habitation supply schedule

\begin{tabular}{|l|l|l|}
\hline Outlets & Source & Timing \\
\hline Aghai branch & \multirow{2}{*}{ MBR } & $11.00 \mathrm{am}-4.00 \mathrm{pm}$ \\
\cline { 1 - 1 } Taharpur branch & & $7.00 \mathrm{am}-11.00 \mathrm{am}$ \\
\hline Dimbhe branch & & $5.00 \mathrm{pm}-6.00 \mathrm{pm}$ \\
\hline
\end{tabular}

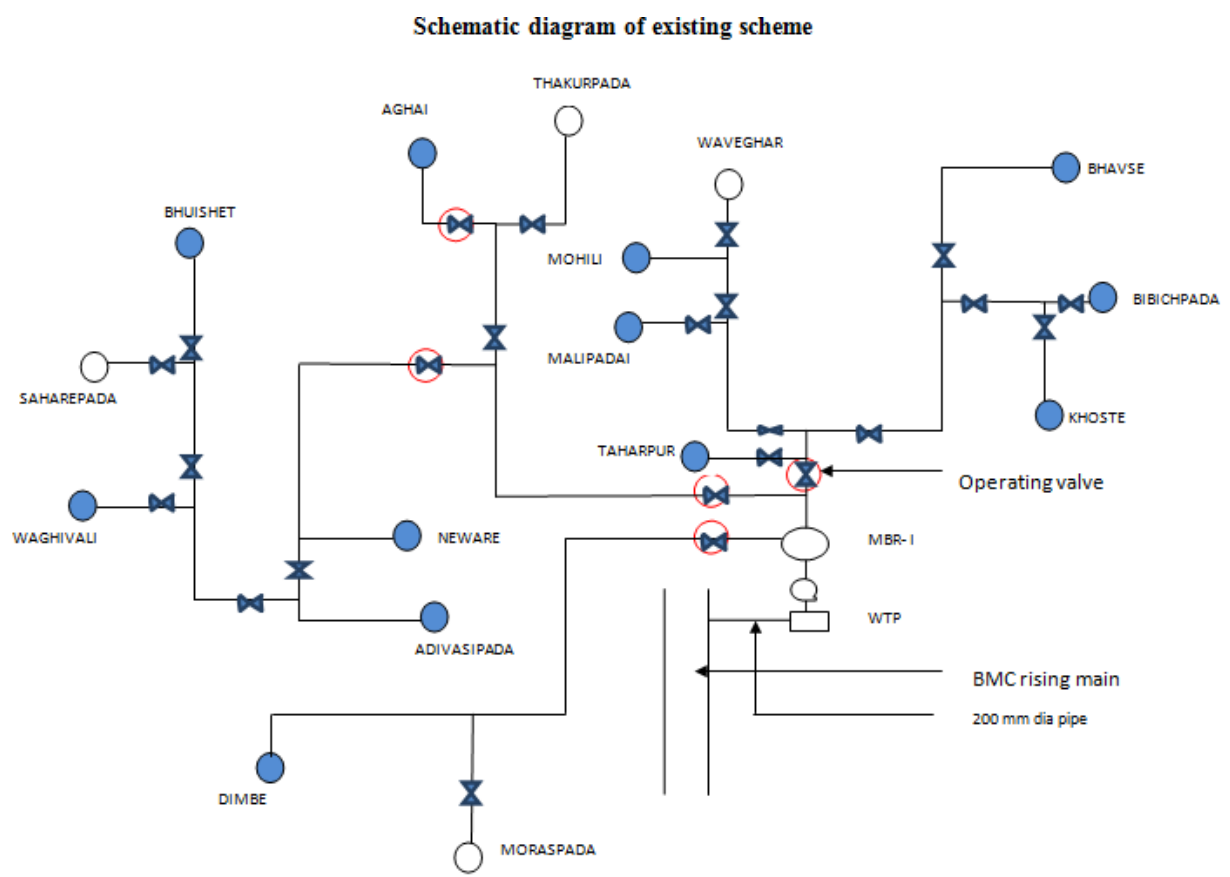

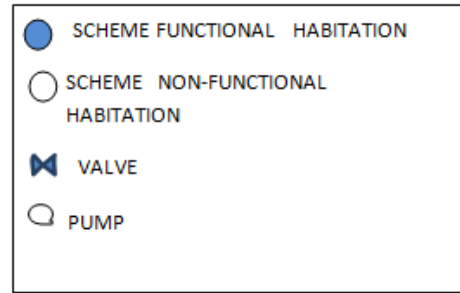


Table 2. Habitation wise scheme status

\begin{tabular}{|l|l|l|}
\hline Habitation & Scheme connected & Remark \\
\hline Aghai & Yes & First ESR is filled and then supplies to household connection \\
\hline Thakurpada & Opt out & ZP School PWS \\
\hline Bhuishet & Yes & Water is supplied to one well once in 15 days \\
\hline Bhavse & Yes & Water is directly supplies to household connection. \\
\hline Bibichapada & Yes & Water is directly supplies to house hold connection \\
\hline Khoste & Yes & Water is directly supplies to house hold connection \\
\hline Dimbhe & Yes & Water is directly supplies to house hold connection \\
\hline Moraspada & Opt out & - \\
\hline Malipada & Yes & Water is directly supplies to house hold connection \\
\hline Taharpur & Yes & Water is directly supplies to house hold connection \\
\hline Mohali & Yes & Water is directly supplies to house hold connection \\
\hline Nevare & Yes & First ESR is filled and then supplied to household connection \\
\hline Adivasipada & Yes & Water is directly supplies to house hold connection \\
\hline Waveghar & Opt out & Hand pump \\
\hline Saharepada & Opt out & Open well \\
\hline Waghiwali & Yes & Water is directly supplies to house hold connection \\
\hline
\end{tabular}

\section{B) Issues in Existing Scheme}

1. As there is only one operator and two valve man working to operate whole scheme. All intermediate valves are kept open on a branch of pipeline serving villages, Therefore there is a less water pressure for all the villages. So this may be the cause that ESRs are not getting filled and no water to the tail end parts of the villages.

2. This scheme is operated and maintained by a contractor appointed by Sahapur rural water supply subdivision. The Recapulation sheet provided by rural water supply subdivision, Shahapur shows the Establishment charges Rs 11,19,528.00. This amount suggests there must be a team of operators who runs the scheme, but at present, only three workers are not possible to single worker to operate all valves.

3. At Mohili village, the distribution line is laid up to midway. The work is not completed at the present stage. So villagers have to go to the end point of the mains which is far away from the villages.

4. On Nevre village line, there is leakage from the air valve; this water is used by villagers for washing of cloths, bathing.

5. Asbestos Cement pipes are used as transmission main in system, so there are chances of pipe bursting as these pipes can sustain very low pressure.

6. As all the villagers are not getting equal amount of water, they are not ready to pay water charges, so collection of water charges has not been done since 2-3 months.

7. The scheduling of valve operation is not done properly, which results into less water pressure at the exit points, therefore some villages had opted out from the scheme.

8. Many villages/habitations which are opt out of scheme do not have any other sustainable scheme. They are now served by either handpumps or wells. Some of opt habitations not getting water only due to leakages in pipes.

9. Leakages in pipes are very high. Bulk water meter reading shows approximately 0.45 million litres of water taken every day but provided is less than that. Many villages/habitation even not get required amount of water.

10. Water treatment plant is totally non-functional. All villagers are getting untreated water for drinking. Only TCL does is applied to water and then pumped to MBRs.

\section{Results and Discussion}

In most of the villages/habitations increase in population is very less or constant so we use arithmetic method for population forecasting. Some villages where population increment is more over a decade we take mean of geometric and arithmetic method. Forecasted population of different decades are 6163, 7586 and 9486 of year 2016, 2031 and 2046 respectively.

Existing Raw water rising main and pure water rising main can be used future. To complete demand of 2031's population 10 BHP pump is require. Capacities of MBR and ESRs are enough to serve todays and future population.

Table 3.Capacities of MBR and ESR different time

\begin{tabular}{|l|l|l|l|l|}
\hline Sr no. & Village/habitation & $\begin{array}{c}\text { Existing ESR capacity } \\
\text { (liters) }\end{array}$ & $\begin{array}{c}\text { Present required capacity } \\
\text { (liters) }\end{array}$ & $\begin{array}{c}\text { Capacity require in } 2046 \\
\text { (liters) }\end{array}$ \\
\hline 1 & MBR & $1,60,000$ & & $2,00,000$ \\
\hline 2 & Aghai & 50,000 & 25,000 & 35,000 \\
\hline 3 & Thakurpada & 8,000 & 8,000 & 1,5000 \\
\hline 4 & Bhuishet & 20,000 & 10,000 & 15,000 \\
\hline
\end{tabular}


Analysis of (Multi Village) Rural Regional Piped Water Supply Scheme - A case study

\begin{tabular}{|l|l|l|l|l|}
\hline 5 & Bhavse & 60,000 & 30,000 & 45,000 \\
\hline 6 & Bibichapada & Not there & 10,000 & 12,000 \\
\hline 7 & Khoste & 5,000 & 20,000 & 30,000 \\
\hline 8 & Dimbhe & 10,000 & 20,000 & 40,000 \\
\hline 9 & Moraspada & 1000 & 1,500 & 2,500 \\
\hline 10 & Malipada & 2000 & 4,500 & 6,500 \\
\hline 11 & Taharpur & 15,000 & 40,000 & 55,000 \\
\hline 12 & Mohali & 10,000 & 20,000 & 30,000 \\
\hline 13 & Nevare & 15,000 & 30,000 & 55,000 \\
\hline 14 & Adivasipada & 4000 & 6,000 & 6,500 \\
\hline 15 & Waveghar & 2000 & 5,000 & 7,000 \\
\hline 16 & Saharepada & 4000 & 2,000 & 2,500 \\
\hline 17 & Waghiwali & 3000 & 7,000 & 7,500 \\
\hline
\end{tabular}

Design of transmission main is done by using BRANCH software. We are suggesting them to change A.C pipes with G.I pipes so we used G.I pipe specification in BRANCH.

This scheme is design for wrong forecasted population. The scheme is designed for the population, 12015 forecasted for the year 2006.Operation and maintenance of scheme is carried out by contractor which is appointed by ZP thane. After three and half year again tender is file for new contractor. Each house hold connection is charged Rs. 60 per month.

1. Layout of Aghai Nevare branch

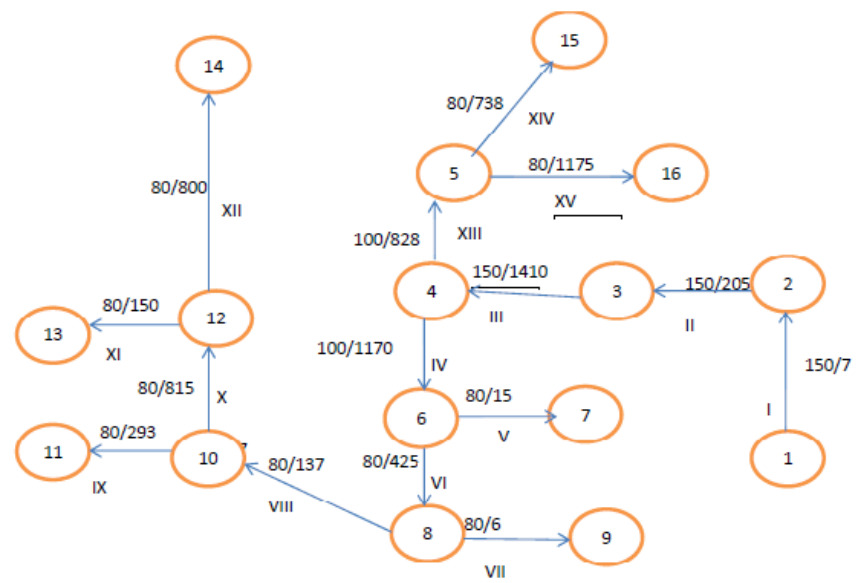

Fig 1 Layout of Aghai - NevareBranch

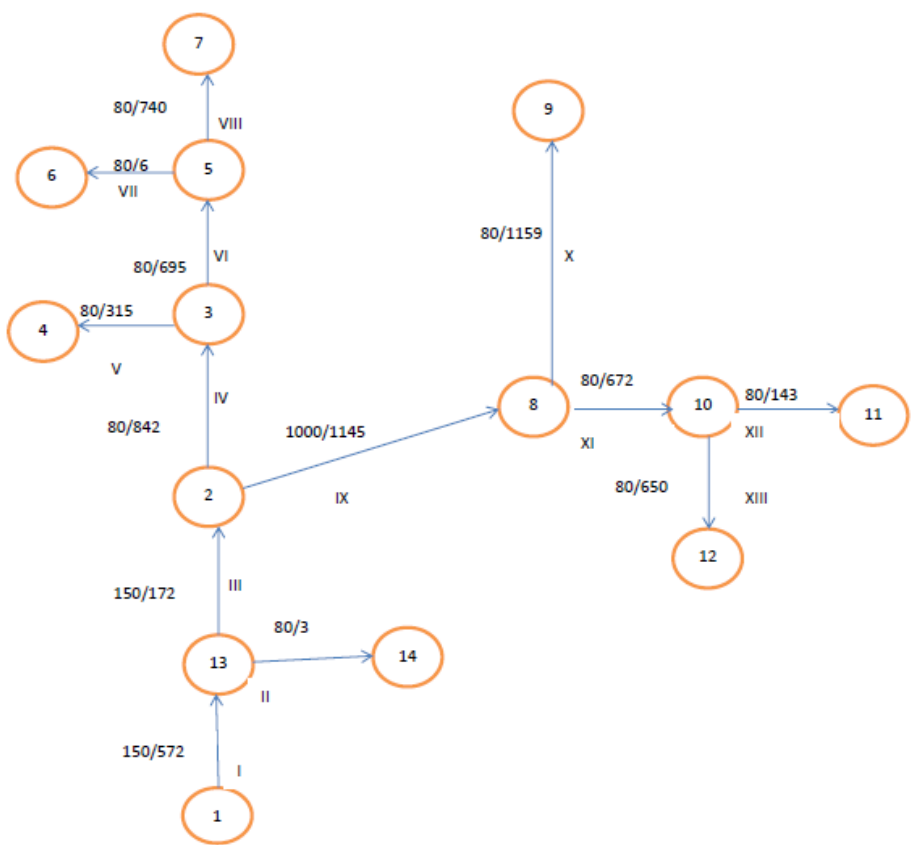

Fig 2 Layout of MohiliBranch 


\section{Conclusion}

The study revealed that the existing pipe water supply scheme was old and insufficient to fulfill the current demand. This scheme has further scope to be used in future with certain replacement of assets and by carrying proper operation and maintenance of scheme.

The modifications in the design are suggested to overcome this issue considering feasibility. Capacities of ESRs at many places are require increasing to full fill present demand. Capacities require today are almost double of existing capacity. Whole transmission main line is required to be replaced. A.C. pipes replace with G.I pipe.

Increasing member of operating team specially operator and valve man, scheme can run smoothly. If valves will properly operate pressure issue can be minimize to large extent. Opt villages can included in scheme without much effort. Fixing problems in WTP it can make functional so that beneficiaries of scheme will get pure water.

\section{Acknowledgement}

This project was undertaken in association with Centre for Technology Alternatives for Rural Areas (CTARA) and Technology and Development Cell (TDSC) of Indian Institute of Technology Bombay (IITB)

\section{References}

[1]. Alexandra V. Kulinkina, Karen C. Kosinski, Alexander Liss, Michael N. Adjei, Gilbert A. Ayamgah , Patrick Webb, David M. Gute, Jeanine D. Plummer, Elena N. Naumova "Piped water consumption in Ghana: A case study of temporal and spatial patterns of clean water demand relative to alternative water sources in rural small towns" ScienceDirect, Science of the Total Environment 559 (2016) 291-301

[2]. ARWSP, 2000 RNDWM, “ARWSP, Guidelines”, RNDWM, 2009

[3]. Brij Pal, "Five Year Plans and Rural Water Supply in India: A Critical Analysis", IISTE, 2012

[4]. Census of India 2011, website http://censusindia.gov.in/pca/cdb_pca_census/Houselisting-housing-Maha.html

[5]. DDWS, GOI, NRDWP Guidelines, 2009

[6]. Detail project report of "Aghai R.R.P.W.S.S" TahsilSahapur District Thane Irrigation Department Z.P. Thane

[7]. Jeffrey P. Waltersa, Paul S. Chinowsky "Planning rural water services in Nicaragua: A systems-based analysis of impact factors using graphical modelling” ScienceDirect, Environmental Science \& Policy 57 (2016) 93-100.

[8]. MrittikaBasu, Satoshi Hoshino, Shizuka Hashimoto "Many issues, limited responses: Coping with water insecurity in rural India" ScienceDirect, Water resources and rural development 5 (2015) 47-63

[9]. Strategic Plan, 2011 DDWS, "Ensuring Drinking Water Security In Rural India”, MDWS, GOI, 2011 